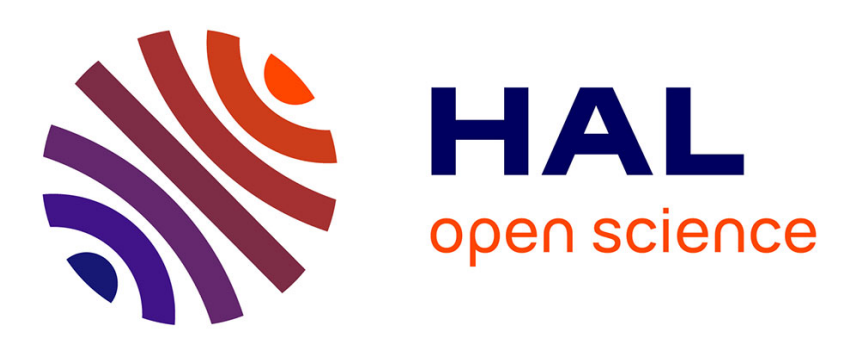

\title{
Bioavailability of starch and postprandial changes in splanchnic glucose metabolism in pigs
}

Lionel Noah, Michel Krempf, Gérard Lecannu, Pascale Maugère, Martine

Champ

\section{- To cite this version:}

Lionel Noah, Michel Krempf, Gérard Lecannu, Pascale Maugère, Martine Champ. Bioavailability of starch and postprandial changes in splanchnic glucose metabolism in pigs. AJP - Endocrinology and Metabolism, 2000, 278 (2), pp.E181-E188. hal-02693333

\section{HAL Id: hal-02693333 \\ https: / hal.inrae.fr/hal-02693333}

Submitted on 1 Jun 2020

HAL is a multi-disciplinary open access archive for the deposit and dissemination of scientific research documents, whether they are published or not. The documents may come from teaching and research institutions in France or abroad, or from public or private research centers.
L'archive ouverte pluridisciplinaire HAL, est destinée au dépôt et à la diffusion de documents scientifiques de niveau recherche, publiés ou non, émanant des établissements d'enseignement et de recherche français ou étrangers, des laboratoires publics ou privés. 


\section{Lionel Noah, Michel Krempf, Gérard Lecannu, Pascale Maugère and Martine}

Champ

Am J Physiol Endocrinol Metab 278:181-188, 2000.

You might find this additional information useful...

This article cites 23 articles, 11 of which you can access free at:

http://ajpendo.physiology.org/cgi/content/full/278/2/E181\#BIBL

This article has been cited by 2 other HighWire hosted articles:

Glucose appearance in the peripheral circulation and liver glucose output in men after a large 13C starch meal

M. Korach-Andre, H. Roth, D. Barnoud, M. Pean, F. Peronnet and X. Leverve

Am. J. Clinical Nutrition, October 1, 2004; 80 (4): 881-886.

[Abstract] [Full Text] [PDF]

Insulin effects on acetate metabolism

H. Piloquet, V. Ferchaud-Roucher, F. Duengler, Y. Zair, P. Maugere and M. Krempf

Am J Physiol Endocrinol Metab, September 1, 2003; 285 (3): E561-E565.

[Abstract] [Full Text] [PDF]

Medline items on this article's topics can be found at http://highwire.stanford.edu/lists/artbytopic.dtl on the following topics:

Medicine .. Carbohydrate Metabolism

Biochemistry .. Glucose Metabolism

Biochemistry .. Starches

Biophysics .. Metabolism

Physiology .. Jugular Veins

Medicine .. Bioavailability

Updated information and services including high-resolution figures, can be found at:

http://ajpendo.physiology.org/cgi/content/full/278/2/E181

Additional material and information about AJP - Endocrinology and Metabolism can be found at:

http://www.the-aps.org/publications/ajpendo

This information is current as of September 3, 2010 .

AJP - Endocrinology and Metabolism publishes results of original studies about endocrine and metabolic systems on any level of organization. It is published 12 times a year (monthly) by the American Physiological Society, 9650 Rockville Pike, Bethesda MD 20814-3991. Copyright ( 2000 by the American Physiological Society. ISSN: 0193-1849, ESSN: 1522-1555. Visit our website at http://www.the-aps.org/. 


\title{
Bioavailability of starch and postprandial changes in splanchnic glucose metabolism in pigs
}

\author{
LIONEL NOAH, ${ }^{1}$ MICHEL KREMPF,2 GÉRARD LECANNU, ${ }^{1}$ \\ PASCALE MAUGERE, ${ }^{2}$ AND MARTINE CHAMP 1 \\ II nstitut National de la Recherche Agronomique, 44316 Nantes; and ${ }^{2} C e n t r e$ \\ de Recherches en Nutrition Humaine, Groupe Métabolisme, 44035 Nantes, France
}

\begin{abstract}
Noah Lionel, Michel Krempf, Gérard Lecannu, Pascale Maugère, and Martine Champ. Bioavailability of starch and postprandial changes in splanchnic glucose metaboIism in pigs. Am. J. Physiol. Endocrinol. Metab. 278: E181E188, 2000.-Changes in splanchnic metabolism in pigs were assessed after meals containing slowly or rapidly digested starch. The pigs were fed a mixed meal containing a "slow" native $(n=5)$ or a "rapid" pregelatinized $(n=5)$ cornstarch naturally enriched with $\left[{ }^{13} \mathrm{C}\right]$ glucose. Absorption of $\left[{ }^{13} \mathrm{C}\right] \mathrm{glu}$ cose was monitored by the arteriovenous difference technique, and infusion of $\mathrm{D}-\left[6,6-2 \mathrm{H}_{2}\right]$ glucose in the jugular vein was used to cal culate the systemi c appearance of $\left[{ }^{13} \mathrm{C}\right]$ gl ucose. Arteriovenous balance data obtained during a 12-h study period showed that the fraction of ingested glucose equivalent appearing as glucose in the portal vein was $49.7 \pm 7.2 \%$ for the slow starch and $48.2 \pm 7.5 \%$ for the rapid starch $(P=$ 0.86). Thesevalues, corrected for the gut extraction of circulating $\left[{ }^{13} \mathrm{C}\right]$ glucose, became $66.4 \pm 5.6$ and $65.3 \pm 5.6 \%$, respectively $(P=0.35)$. I sotope dilution data indicated that systemic appearance of exogenous $\left[{ }^{13} \mathrm{C}\right]$ glucose represented $62.9 \pm$ 7.6 and $67.4 \pm 3.0 \%$ of the oral load for slow and rapid starch, respectively $(P=0.68)$. Arterial glucose utilization by the gut increased from $7.3 \pm 0.9 \mu \mathrm{mol} \cdot \mathrm{kg}^{-1} \cdot \mathrm{min}^{-1}$ before the meal to $8.5 \pm 1.6 \mu \mathrm{mol} \cdot \mathrm{kg}^{-1} \cdot \mathrm{min}^{-1}$ during absorption, independently of the nature of the starch. Thus splanchnic glucose metabolism was unaffected by the nature of starch ingested.
\end{abstract}

starch; glucose metabol ism; stable isotope

THE RATE OF ABSORPTION is probably a key factor in splanchnic metabolism, because it regulates insulin secretion or action $(20,27)$. Although long-term consumption of slowly digested starches can prevent the development of insulin resistance $(12,20,27)$ and obesity $(15,27)$ in rats, the postprandial effects of starch ingestion on splanchnic glucose metabolism are not clearly known. This is especially true when starch is ingested with other food products, which can affect its bioavailability. Most studies in animal models have been performed with glucose, and data have usually been obtained by the arteriovenous balance technique. The isotope dilution method (dual tracer approach), which has been frequently used in humans, can provide further information on splanchnic metabolism. I sotope

The costs of publication of this article were defrayed in part by the payment of page charges. The article must therefore be hereby marked "advertisement" in accordance with 18 U.S.C. Section 1734 solely to indicate this fact. dilution, which is a noninvasive method, has shown that postprandial splanchnic metabolism is characterized by exogenous glucose retention ( $\leq 30 \%$ of the ingested load) and suppression of endogenous glucose production ( $\leq 80 \%$ of basal production) $(9,13,16,23)$. Although the use of both arteriovenous balance and isotope dilution techniques can provide much information about splanchnic metabolism, comparisons have rarely been made between the data obtained from the two techniques. The aim of the present study was to evaluate the impact of the bioavailability of starch on splanchnic metabolism. For that purpose, pigs were given two fully digestible cornstarches naturally enriched with $\left[{ }^{13} \mathrm{C}\right]$ glucose, characterized as rapidly (pregelatinized) or slowly (native) digestible starch. The two complementary techniques of arteriovenous balance across the gut and isotope dilution were used to assess the changes in splanchnic metabolism after the meals.

\section{METHODS}

\section{Animals and Surgery}

Studies were conducted on six conscious 24-h-fasted female Large White pigs, weighing 40-48 kg (mean: $43.7 \pm 1.4 \mathrm{~kg}$ ) at the time of the experiment. The animals were purchased from the Institut National de la Recherche Agronomique (INRA) Research Centre of Saint Gilles, France.

Approximately 1-2 wk before the study, the animals underwent general anesthesia $\left(\mathrm{O}_{2}, \mathrm{~N}_{2} \mathrm{O}\right.$, halothane). They were fitted with polyvinyl catheters (Tygon Norton, Cleveland, $\mathrm{OH}$ ) in the jugular vein (1.6 mm ID, $3.2 \mathrm{~mm} \mathrm{OD})$, portal vein, and carotid artery (1.3 mm ID, $2.3 \mathrm{~mm} \mathrm{OD}$ ), and a flow probe (T206; Transonic Systems, Ithaca, NY) was positioned around the portal vein according to the technique previously described by Rérat et al. (24). The animals were allowed a minimum of 7 days for recovery after surgery. The experiment did not begin until they had recovered normal dietary intake and normal stools. The pigs werekept at room temperature in individual cages and were fed twice a day (9 AM and 4 PM) with the preexperimental diet. Animal treatment was al ways in accordance with French legislation.

\section{Diets}

Starches. The two purified cornstarches used in this study were supplied by Roquette Industries (Lestrem, France). These native ("standard", slowly digestible) and pregelatinized ("Pregeflo M," rapidly digestible) starches are totally digestible in the small intestine. Two pigs were fitted with an ileal cannula by the technique of van Leeuwen et al. (31) to obtain ileal effluents for starch measurements. The fraction of ingested starch entering the col on of these animals during the 
first $12 \mathrm{~h}$ after a meal was, respectively, 0.65 and $0.73 \%$ for pregelatinized starch and 0.46 and $0.30 \%$ for native starch. Only $2.8 \%$ (pregelatinized starch) and $0.8 \%$ (native starch) of the oral load still remained within the gut lumen after the pigs were killed at $12 \mathrm{~h}$. The amounts of available glucose equivalent supplied by the two products were $207.7 \mathrm{~g}$ (native starch) and $198.0 \mathrm{~g}$ (pregelatinized starch).

Although both starches were highly digestible, the susceptibility of starch to hydrolysis was greater for pregelatinized than for native starch, as measured by the method of Bornet et al. (3). After 30 and 180 min of incubation with $\alpha$-amylase, the proportion of starch converted to al cohol-soluble maltooligosaccharides was, respectively, $65 \pm 1$ and $71 \pm 3 \%$ for pregelatinized starch $(n=2)$ and only $8 \pm 1$ and $22 \pm 1 \%$ for native starch $(n=2)$.

Experimental meals. Two experimental meals providing $5,720 \mathrm{~kJ}$ (31\% from lipids, 16\% from proteins, and $53 \%$ from carbohydrates) were given to the pigs (Table 1). The mixed meals contained either "sl ow" native or "rapid" pregelatinized starch.

\section{Experimental Design}

Each pig received the two experimental meals in randomized order, with an interval of 1 wk between experiments. Two pigs got only one of the two experimental meals. A total of 10 experiments was performed for the entire protocol ( 5 for the slow starch meal and 5 for the rapid starch meal). One week before the study, the pigs were fed a meal without naturally ${ }^{13} \mathrm{C}$-enriched foods (Table 1). At $7 \mathrm{AM}$ on the day of the experiment ( $\mathrm{t}=-120 \mathrm{~min})$, a bolus of tracer $(22 \mathrm{mmol} / \mathrm{kg}$ body wt; D-[6,6-2 $\left.\mathrm{H}_{2}\right]$ glucose, 99 mol\% enrichment, $\mathrm{CIL}$, Andover, MA) was injected into the jugular vein, and constant infusion was begun at a rate of $20 \mu \mathrm{mol} \cdot \mathrm{kg}^{-1} \cdot \mathrm{h}^{-1}$. This sterile, pyrogen-free saline solution was infused through an 0.2-mm Millipore filter. After $120 \mathrm{~min}$ (time 0), the pigs were fed the experimental meal. Portal vein blood flow was continuously recorded, and blood samples weretaken from the portal vein and the carotid artery from -30 min before the meal until the end of the study $(\mathrm{t}=720 \mathrm{~min})$.

Blood samples $(5 \mathrm{ml})$ were taken every $15 \mathrm{~min}$ during the first $4 \mathrm{~h}(\mathrm{t}=-120 \mathrm{~min}$ to $\mathrm{t}=120 \mathrm{~min})$, every $30 \mathrm{~min}$ during the next $3 \mathrm{~h}(\mathrm{t}=120 \mathrm{~min}$ to $\mathrm{t}=300 \mathrm{~min})$, and then every hour until the end of the study ( $t=300 \mathrm{~min}$ to $t=720 \mathrm{~min}$ ). Blood was collected in heparinized tubes (Terumo, Leuven, Belgium) and centrifuged $\left(9,000 \mathrm{~g}\right.$ for $10 \mathrm{~min}$ at $\left.4^{\circ} \mathrm{C}\right)$. Plasma was isolated and kept at $-20^{\circ} \mathrm{C}$ until analyzed.

Table 1. Composition of experimental and preexperimental meals

\begin{tabular}{|c|c|c|c|}
\hline & \multirow{2}{*}{$\begin{array}{l}\text { Preexperimental } \\
\text { Meal }\end{array}$} & \multicolumn{2}{|c|}{ Experimental Meals } \\
\hline & & Diet $\mathrm{N}$ & Diet $\mathrm{P}$ \\
\hline & \multicolumn{3}{|c|}{ g/ kg dry matter } \\
\hline Native corn startch* & & 573 & \\
\hline Pregelatinized corn starch* & & & 563 \\
\hline Pregelatinized potato starch* & 393 & & \\
\hline Native wheat starch* & 119 & & \\
\hline Meat meal & 291 & 307 & 314 \\
\hline Soyabean oil & 109 & 115 & 118 \\
\hline Wheat bran & 81 & & \\
\hline Pea hulls & 5 & 5 & 5 \\
\hline
\end{tabular}

Diet $\mathrm{N}$ is a native starch meal, and diet $\mathrm{P}$ is a pregelatinized starch meal. Preexperimental meal consisted of $430 \mathrm{~g}$. Experimental diet (326 g for diet $\mathrm{N}$, and $318 \mathrm{~g}$ for diet $\mathrm{P}$ ) provided $\sim 5,720 \mathrm{~kJ}$. Meals were mixed with water at a ratio of 1 to 3 (wt/vol). *Starches were supplied by Roquette Industries, Lestrem, France.

\section{Analytical Procedures}

${ }^{13} \mathrm{C}$ enrichment of starch. The ${ }^{13} \mathrm{C}$ enrichment of glucose from starch was determined by the gas chromatographycombustion-isotope ratio mass spectrometry (GC-C-IRMS) method described by Tissot et al. (29). Native and pregelatinized starches were first hydrolyzed into glucose by use of a method modified by Thivend et al. (28). Five hundred milligrams of starch, mixed with $25 \mathrm{ml}$ of distilled water, were heated at $100^{\circ} \mathrm{C}$ for $30 \mathrm{~min}$. Then $2.5 \mathrm{ml}$ of acetate buffer $(\mathrm{pH}=4.6)$ were added, and the solution was completed with $45 \mathrm{ml}$ of distilled water. Ten milligrams of amyloglucosidase (thermostable, Merck-Clévenot, Nogent-sur-Marne, France, cat. no. 1.01332, 2217 nKat/mg glucose equivalent) were added. Hydrolysis was stopped after $2 \mathrm{~h}$ of incubation by heating the solution at $100^{\circ} \mathrm{C}$ for $10 \mathrm{~min}$. The hydrolysis products were then extracted by adding $188 \mathrm{ml}$ of pure ethanol and mixing and centrifuging at 1,500 g (10 min). Supernatant was isolated and evaporated under vacuum. Glucose was then derivatized to glucose pentaacetate (21). The derivatized product was diluted in $1 \mathrm{ml}$ of ethyl acetate (Sigma-Aldrich Chimie), and a sample ( $1 \mu \mathrm{l}$ ) was injected into a gas chromatograph (capillary column $30 \mathrm{~m} \times 0.32 \mathrm{~mm} \times$ $0.25 \mu \mathrm{m}$, type DB1, J W Scientific, Courtaboeuf, France). The gas chromatograph was coupled to a combustion furnace $\left(\mathrm{CuO}, \mathrm{NiO}, \mathrm{Pt}, 940^{\circ} \mathrm{C}\right)$, and an isotope ratio mass spectrometer (Delta S, Finnigan Mat, Bremen, Germany). I sotopomeric ions of $\mathrm{CO}_{2}$ were separated and recorded according to their mass-to-charge ratio (m/ z) $(44,45$, or 46$)$. A standard $\mathrm{CO}_{2}$ sample of known enrichment was injected intermittently to ensure the high precision of measurements.

Plasma variables. Plasma glucose was measured by the glucose-oxidase method (Glucose Analyzer II, Beckman, Fullerton, CA). Insulin was measured by radioimmunoassay (ORIS, Gif sur Yvette, France). Plasma lactate was analyzed using an enzymatic test kit (Boehringer Mannheim, Meylan, France, cat. no. 139084).

Plasma $\left[{ }^{2} \mathrm{H}_{2}\right]$ glucose and $\left[{ }^{13} \mathrm{C}\right]$ gl ucose isotopic enrichment. Fifty microliters of plasma were deproteinized by addition of $300 \mu \mathrm{l}$ acetone. After $10 \mathrm{~min}$ at $4^{\circ} \mathrm{C}$, the tube was centrifuged for $10 \mathrm{~min}$ at $4,000 \mathrm{~g}$, and the supernatant was isolated. The supernatant was then evaporated under nitrogen, and the sample was derivatized.

${ }^{13} \mathrm{C}$ plasma glucose enrichment $\left(\delta^{13} \mathrm{C} \%\right.$ was analyzed by the GC-C-IRMS method we have described.

Plasma D-[6,6-2 $\mathrm{H}_{2}$ ]glucose was analyzed by GC coupled to MS (Hewlett-Packard MSD 5971A, Les Ulis, France) by use of a previously described method (14).

\section{Calculations}

Net $\left[{ }^{13} \mathrm{C}\right]$ gl ucoseand lactate bal anceacross the gut. N et gut balance (NGB) was calculated according to the formula described by Rérat et al. (24)

$$
\mathrm{NGB}=\Sigma\left(\mathrm{C}_{\mathrm{pv}}-\mathrm{C}_{\mathrm{ca}}\right) \cdot \mathrm{PVF} \cdot \mathrm{dt}
$$

where $C_{p v}$ and $C_{c a}$ are the $\left[{ }^{13} C\right.$ ]glucose (exogenous glucose) or lactate concentrations in portal vein and carotid artery blood, respectively, and PVF is the portal vein blood flow during the studied time interval (dt). Plasma concentrations were converted into whole blood concentrations using the $(1-0.3 \times$ hematocrit) correction factor proposed by Dillon (6).

The fraction of vascular glucose extracted by the gut (\%) was cal culated as follows

$$
\text { gut fractional extraction }=\left[\left(D_{c a}-D_{p v}\right) / D_{c a}\right] \cdot 100
$$


where $D_{c a}$ and $D_{p v}$ are the $\mathrm{D}-\left[6,6-{ }^{2} \mathrm{H}_{2}\right]$ glucose concentrations in carotid artery and portal vein plasma, respectively.

The extraction ratio of vascular glucose was then used to correct the net $\left[{ }^{13} \mathrm{C}\right]$ glucose balance across the gut. To take into account the gut extraction of recirculating glucose, arterial flux of $\left[{ }^{13} \mathrm{C}\right]$ glucose was multiplied by the gut extraction ratio. The obtained value was added to the net portal $\left[{ }^{13} \mathrm{C}\right]$ glucose flux.

Rate of glucose appearance in the systemic pool. The isotopic abundance of the samples was expressed in ${ }^{13} \mathrm{C}$ atom $\%$ (AP). The AP of ingested and plasma glucose was transformed into atom \% excess (APE) by the following formula: $A P E=A P_{s}-A P_{b}$, where $A P_{s}$ is the AP of the plasma sample, and $A P_{b}$ is the AP of plasma glucose before the meal.

The rate of glucose appearance (RaT, $\mathrm{mol} \cdot \mathrm{kg}^{-1} \cdot \mathrm{min}^{-1}$ ) was calculated from the ${ }^{2} \mathrm{H}_{2}$ enrichment of plasma glucose according to the equation of Steele (26), as modified by De Bodo et al. (5)

$$
\text { RaT }=\frac{F-V \cdot p \cdot\left[\left(G_{1}+G_{2}\right) / 2\right] \cdot\left[\left(M P E_{2}-M P E_{1}\right) /\left(t_{2}-t_{1}\right)\right]}{\left(M P E_{2}+M P E_{1}\right) / 2}
$$

where $F$ is the infusion rate of tracer $D-\left[6,6-2 \mathrm{H}_{2}\right]$ glucose $\left(\mathrm{mol} \cdot \mathrm{kg}^{-1} \cdot \mathrm{min}^{-1}\right), \mathrm{MPE}_{1}$ and $\mathrm{MPE}_{2}$ are the mol \% excess values of $\left[{ }^{2} \mathrm{H}_{2}\right]$ glucose of plasma glucose, respectively, at time $\mathrm{t}_{1}$ and $\mathrm{t}_{2}(\mathrm{~min})$, and $\mathrm{G}_{1}$ and $\mathrm{G}_{2}(\mathrm{~mol})$ are the plasma glucose concentrations, respectively, at times $t_{1}$ and $t_{2}$. The distribution volume $(\mathrm{V})$ was assumed to be $0.2 \mathrm{l} / \mathrm{kg}$, and a pool fraction value (p) of 0.65 was chosen for the study (19).

The rate of appearance of exogenous glucose in the systemic pool $\left(\mathrm{RaE}, \mathrm{mol} \cdot \mathrm{kg}^{-1} \cdot \mathrm{min}^{-1}\right)$ was calculated from the enrichment of derivatized plasma [ $\left.{ }^{13} \mathrm{C}\right]$ glucose, according to the formula suggested by Proietto et al. (22)

$$
R a E=\frac{\begin{array}{l}
{\left[R a T \cdot\left(A P E_{1}+A P E_{2}\right) / 2\right]} \\
+\left[V \cdot p \cdot\left(G_{1}+G_{2}\right) / 2 \cdot\left(A P E_{2}-A P E_{1}\right) /\left(t_{2}-t_{1}\right)\right]
\end{array}}{A P E_{\text {glu.ing }}}
$$

where $A P E_{1}$ and $A P E_{2}$ are the ${ }^{13} \mathrm{C}$ enrichments of plasma glucose, respectively, at time $t_{1}$ and $t_{2}(\min )$, and $A P E_{\text {glu.ing }}$ is the AP excess of ingested glucose.

Endogenous glucose production (Rae) was calculated by subtracting RaE from RaT. The suppression of Rae caused by the meal was calculated as follows

(basal production

- postprandial endogenous production)

basal production

where basal production is the mean Raebefore the meal.

Statistical Analysis

Statistical analyses involved standard error of the mean (SE ), the Mann-Whitney test to compare the mean enrichments of native and pregelatinized cornstarch, and two-way analysis of variance to determine the effects of animals and test meals on metabolic variables. Analyses were performed using the Statgraphics 3.0 software package (STSC, Rockville, MD).

\section{RESULTS}

\section{${ }^{13} \mathrm{C}$ Enrichment of Starch}

After the starches were enzymatically hydrolyzed, no difference was observed between the ${ }^{13} \mathrm{C}$ enrichments of derivatized glucose from slow or rapid starch $(P=$
0.87). The mean ${ }^{13} \mathrm{C}$ enrichment of derivatized glucose was $1.0753 \pm 0.0001(n=12)$ atom $\%{ }^{13} \mathrm{C}(A P)$.

\section{Absorption and Gut Metabolism (Arteriovenous} DifferenceTechnique)

Portal blood flow. Basal portal blood flows were $21.25 \pm 1.05 \mathrm{ml} \cdot \mathrm{kg}^{-1} \cdot \mathrm{min}^{-1}(\mathrm{n}=5)$ and $21.07 \pm 0.65$ $(\mathrm{n}=5) \mathrm{ml} \cdot \mathrm{kg}^{-1} \cdot \mathrm{min}^{-1}$, respectively, for slow starch and rapid starch meals ( $P=0.36)$. Portal flows increased to a mean of $31.43 \pm 2.01 \mathrm{ml} \cdot \mathrm{kg}^{-1} \cdot \mathrm{min}^{-1}$ at $45 \mathrm{~min}$ (slow starch) and $30.57 \pm 2.18 \mathrm{ml} \cdot \mathrm{kg}^{-1} \cdot \mathrm{min}^{-1}$ at $90 \mathrm{~min}$ (rapid starch) during the postprandial period, and they returned to the basal level after $420 \mathrm{~min}$. There was no difference between average portal flows measured after meals $\left(25.21 \pm 1.59\right.$ and $25.50 \pm 1.17 \mathrm{ml} \cdot \mathrm{kg}^{-1} \cdot \mathrm{min}^{-1}$ for slow and rapid starch, respectively; $P=0.55)$.

Glucose. Basal arterial plasma glucose concentration was not different between theslow starch meals (4.71 \pm $0.14 \mathrm{mmol} / \mathrm{l} ; \mathrm{n}=5$ ) and the rapid starch meals (4.55 \pm $0.19 \mathrm{mmol} / \mathrm{l} ; \mathrm{n}=5)(\mathrm{P}=0.30)$. Mean gut fractional extraction of glucose during thestudy was 7.6 \pm 1.4 and $7.7 \pm 2.5 \%$, respectively, for slow starch and rapid starch meals ( $P=0.16)$. The fraction of arterial glucose extracted by the gut decreased after the meal and was minimal at $30 \mathrm{~min}$ for slow starch and at $90 \mathrm{~min}$ for rapid starch (Fig. 1). In basal state, the mean rate of arterial glucose utilization by the gut was $6.6 \pm 1.3$ $\mu \mathrm{mol} \cdot \mathrm{kg}^{-1} \cdot \mathrm{min}^{-1}$ for slow starch and $7.5 \pm 1.4 \mu \mathrm{mol} \cdot$ $\mathrm{kg}^{-1} \cdot \mathrm{min}^{-1}$ for rapid starch $(P=0.91)$ (mean for both starches was $\left.7.3 \pm 0.9 \mu \mathrm{mol} \cdot \mathrm{kg}^{-1} \cdot \mathrm{min}^{-1}\right)$. Under the meal fed condition, this rate was $8.8 \pm 1.3$ and $8.3 \pm 3.2$ $\mu \mathrm{mol} \cdot \mathrm{kg}^{-1} \cdot \mathrm{min}^{-1}$, respectively, for slow and rapid starch $(P=0.20)$ (mean for both starches was $8.5 \pm 1.6$ $\left.\mu \mathrm{mol} \cdot \mathrm{kg}^{-1} \cdot \mathrm{min}^{-1}\right)$. During absorption, the total amount of arterial glucose extracted was $57.4 \pm 11.3 \mathrm{~g}$ for slow starch and $51.3 \pm 20.0 \mathrm{~g}$ for rapid starch $(P=0.20)$.

Plasma glucose ${ }^{13} \mathrm{C}$ enrichment in portal vein increased immediately after the meals and reached a

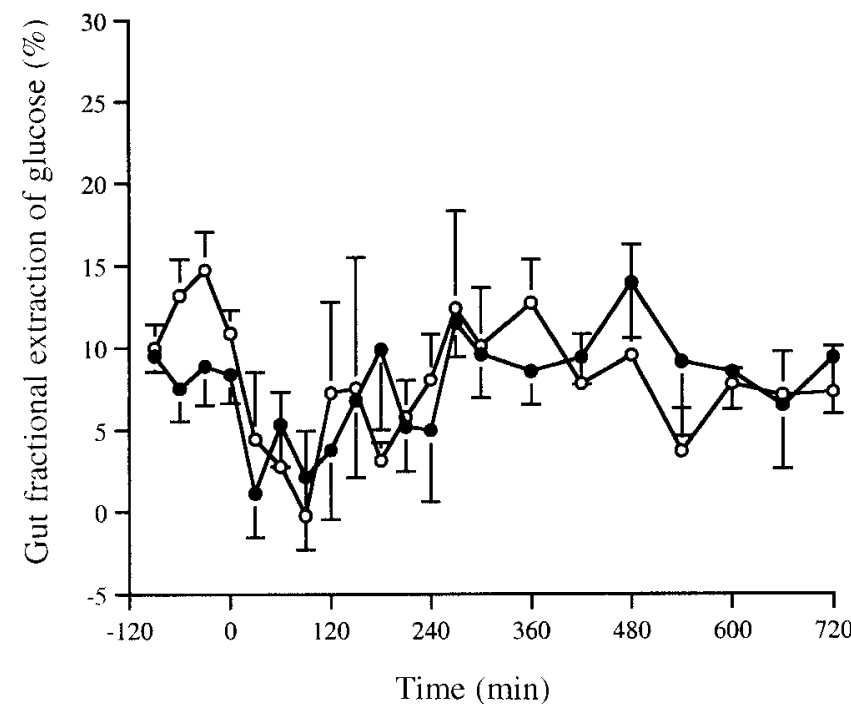

Fig. 1. Gut fractional extraction of glucose during control period $(-120$ to 0 min) and after slow starch meal ( $\bullet$ ) and rapid starch meal (O). Values are means $\pm S E ; n=5$. Time 0 is beginning of experimental meal. 
plateau at $\sim 75$ min both for slow starch $(\approx 0.0135 \mathrm{APE})$ and for rapid starch $(\approx 0.0150$ APE $)(P=0.23)$ (Fig. 2$)$. For both meals, glucose ${ }^{13} \mathrm{C}$ enrichment remained relatively high at the end of the study $(\approx 0.0100 \mathrm{APE})$. At that time, enrichments were not significantly different between portal vein and carotid artery, either for slow starch $(P=0.06)$ or for rapid starch $(P=0.11)$.

As shown in Fig. 3, net absorption of $\left[{ }^{13} \mathrm{C}\right]$ glucose lasted until 720 min after the meals. The cumulated amount of "absorbed" $\left.{ }^{13} \mathrm{C}\right]$ glucose tended to be lower $(P=0.05)$ for the slow starch than for the rapid starch meal during the first $90 \mathrm{~min}$ (respectively, $30.9 \pm 4.6$ and $37.8 \pm 3.5 \mathrm{~g}$ ) and $105 \mathrm{~min}$ (respectively, $36.1 \pm 5.3$ and $44.3 \pm 4.7 \mathrm{~g}$ ). The amounts of $\left[{ }^{13} \mathrm{C}\right]$ glucose appearing in the portal vein during the $720 \mathrm{~min}$ of the experiment were $103.2 \pm 15.0 \mathrm{~g}(49.7 \pm 7.2 \%$ of the ingested amount) and $95.5 \pm 14.9 \mathrm{~g}(48.2 \pm 7.5 \%$ of the ingested amount) for the slow starch meal $(n=5)$ and

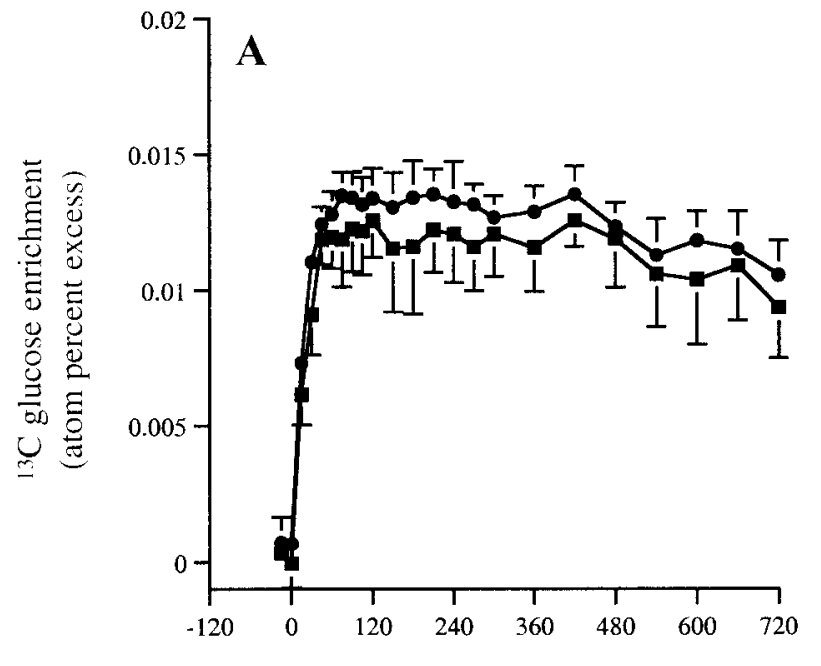

Time (min)

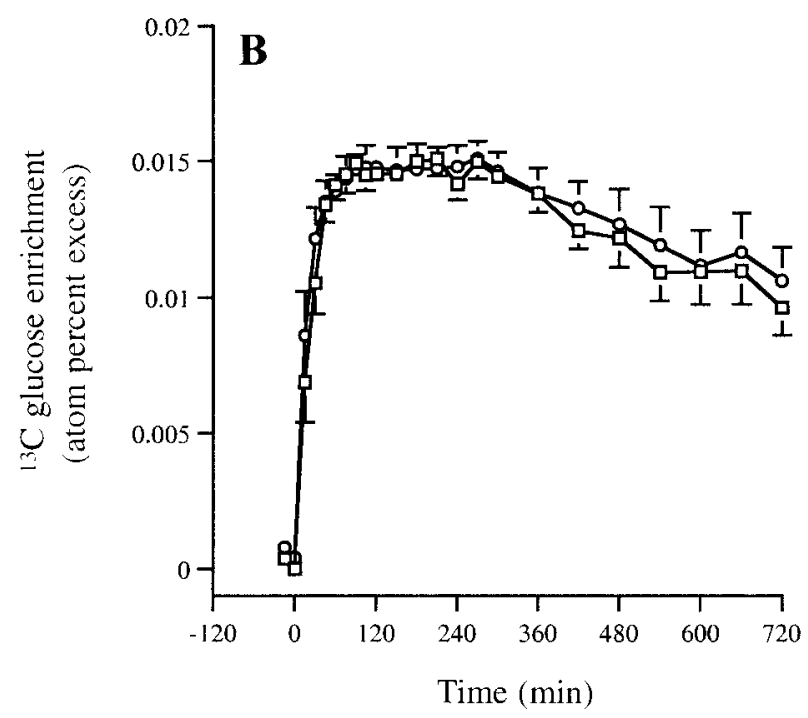

Fig. 2. Changes in derivatized plasma glucose ${ }^{13} \mathrm{C}$ enrichment (expressed in atom \% excess) during portprandial period in portal vein (circles) and carotid artery (squares) for slow starch (A) and rapid starch (B). Values are means $\pm S E ; n=5$. Time 0 is beginning of experimental meal.
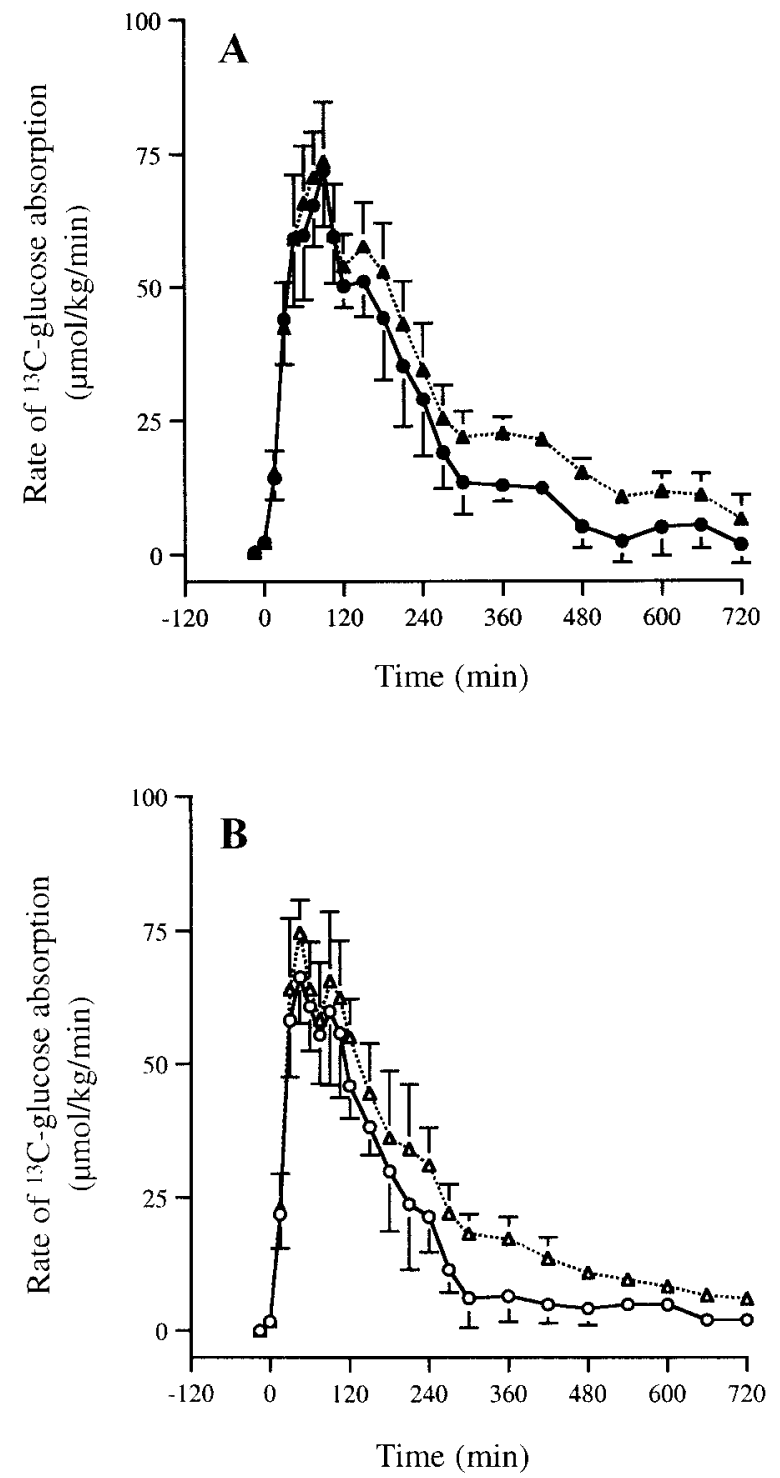

Fig. 3. Rates of $\left[{ }^{13} \mathrm{C}\right]$ glucose absorption calculated by use of balance of $\left[{ }^{13} \mathrm{C}\right]$ glucose across gut without correction (circles) or after correction for recycled $\left[{ }^{13} \mathrm{C}\right]$ glucose uptake by intestine (triangles, dotted lines) for slow starch meal (A) and rapid starch meal (B). Values are means $\pm S E ; n=5$. Time 0 is beginning of experimental meal.

the rapid starch meal $(n=5)$, respectively (difference not statistically significant, $\mathrm{P}=0.86$ ). When net balance of $\left[{ }^{13} \mathrm{C}\right] \mathrm{glucose}$ across the gut was corrected for the extraction of circulating $\left[{ }^{13} \mathrm{C}\right]$ glucose, the rates of $\left[{ }^{13} \mathrm{C}\right]$ glucose absorption were still found to be $6.5 \pm 4.6$ and $6.0 \pm 1.9 \mu \mathrm{mol} \cdot \mathrm{kg}^{-1} \cdot \mathrm{min}^{-1}$ for the slow starch meal $(n=5)$ and the rapid starch meal $(n=5)$, respectively, at the end of the study (Fig. 3). Corrected for the extraction of circulating $\left[{ }^{13} \mathrm{C}\right]$ glucose, the total amounts of absorbed $\left[{ }^{13} \mathrm{C}\right]$ glucose during the $720 \mathrm{~min}$ of the experiment were $137.8 \pm 11.6 \mathrm{~g}$ for the slow starch $(66.4 \pm 5.6 \%$ of theingested amount) and $129.3 \pm 11.0 \mathrm{~g}$ for the rapid starch $(65.3 \pm 5.6 \%$ of the ingested amount) $(P=0.35)$.

Insulin. Arterial plasma insulin concentration was $34.3 \pm 7.3 \mathrm{pmol} / \mathrm{l}(\mathrm{n}=5)$ and $37.1 \pm 13.8 \mathrm{pmol} / \mathrm{l}(\mathrm{n}=5)$ before the slow starch and rapid starch meals ( $P=$ 0.99). Maximal increment over basal state, obtained 30 
min after the beginning of the meal (Fig. 4), was $216.4 \pm 46.8$ and $247.5 \pm 41.7 \mathrm{pmol} / \mathrm{l}$, respectively $(\mathrm{P}=$ $0.77)$. No difference was observed between the two meals for the area under the postprandial curve of insulin $(P=0.88)$.

Lactate. Mean arterial lactate concentration was $0.62 \pm 0.08 \mathrm{mmol} / \mathrm{l}(\mathrm{n}=5)$ and $0.65 \pm 0.09 \mathrm{mmol} / \mathrm{l}(\mathrm{n}=$ $5)$, respectively, before the slow starch and rapid starch meals $(P=0.83)$. Net production of lactate by the gut occurred during the absorption period, and the rate of production at maximum level ( $30 \mathrm{~min}$ ) was not significantly different $(P=0.10)$ between the two meals $\left(13.0 \pm 1.3 \mu \mathrm{mol} \cdot \mathrm{kg}^{-1} \cdot \mathrm{min}^{-1}\right.$ for slow starch and $13.0 \pm$ $1.2 \mu \mathrm{mol} \cdot \mathrm{kg}^{-1} \cdot \mathrm{min}^{-1}$ for rapid starch; $\mathrm{n}=5$ ). The total production of lactate by the gut amounted to $7.3 \pm 1.4 \mathrm{~g}$ ( $3.5 \pm 0.7 \%$ of the glucose equivalent ingested; $n=5$ ) and $6.7 \pm 0.7 \mathrm{~g}(3.3 \pm 0.3 \%$ of the glucose equivalent ingested; $n=5$ ) for slow starch and rapid starch meals, respectively (difference not statistically significant, $\mathrm{P}=$ 0.35).

\section{I sotope Dilution Data}

Rate of systemic appearance of glucose. The rate of total glucose appearance (RaT) was $17.23 \pm 1.18$ and $13.92 \pm 1.11 \mu \mathrm{mol} \cdot \mathrm{kg}^{-1} \cdot \mathrm{min}^{-1}$, respectively, before the slow starch meal $(n=5)$ and the rapid starch meal $(n=$ 5) $(P=0.10)$. Glucose production increased to maximal values at $90 \mathrm{~min}$ for slow starch (70.25 \pm 9.08 $\left.\mu \mathrm{mol} \cdot \mathrm{kg}^{-1} \cdot \mathrm{min}^{-1}\right)$ and at $75 \mathrm{~min}$ for rapid starch $\left(61.35 \pm 3.49 \mu \mathrm{mol} \cdot \mathrm{kg}^{-1} \cdot \mathrm{min}^{-1}\right)(\mathrm{P}=0.45)$.

Systemic appearance of endogenous and exogenous glucose. During absorption, endogenous glucose production was suppressed an average of $59.9 \pm 8.3 \%(n=5)$ after the slow starch meal and $69.7 \pm 5.7 \%(n=5)$ after the rapid starch meal (Table 2), corresponding to equivalent amounts of glucose retained in the splanchnic bed of $59.0 \pm 10.2 \mathrm{~g}$ and $54.8 \pm 6.5 \mathrm{~g}$, respectively $(P=0.55)$ (Fig. 5).

The rate of systemic appearance of exogenous [ $\left.{ }^{13} \mathrm{C}\right] \mathrm{glu}$ cose $(\mathrm{RaE})$ increased to maximal values of $58.28 \pm 9.38$

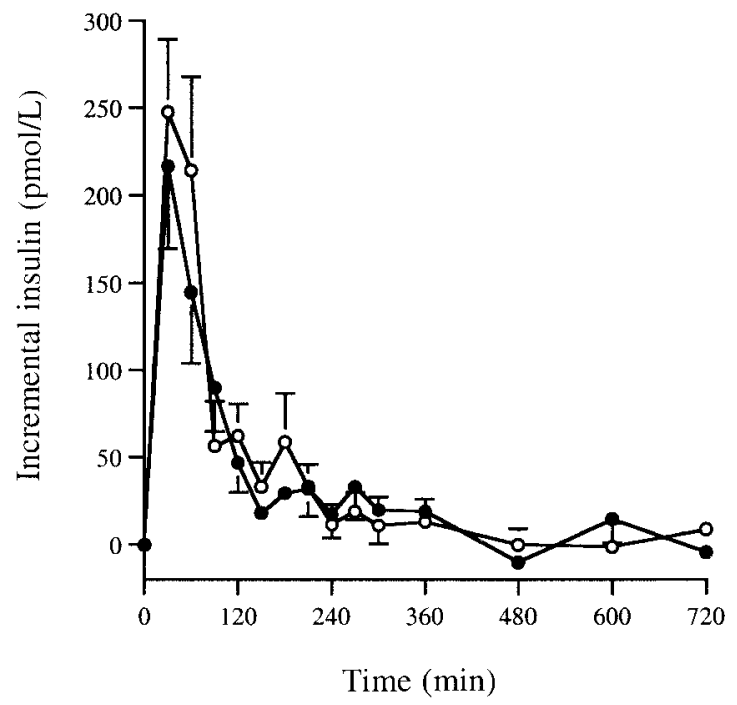

Fig. 4. Incremental insulin concentration in arterial plasma after slow starch meal $(\bullet)$ and rapid starch meal $(O)$. Values are means \pm $\mathrm{SE} ; \mathrm{n}=5$. Time 0 is beginning of experimental meal.
Table 2. Splanchnic glucose metabolism during absorption

\begin{tabular}{|c|c|c|}
\hline & $\begin{array}{l}\text { Native } \\
\text { Starch }\end{array}$ & $\begin{array}{l}\text { Pregelatinized } \\
\text { Starch }\end{array}$ \\
\hline Ingested $\left[{ }^{13} \mathrm{C}\right]$ glucose equivalent, $\mathrm{g}$ & 207.7 & 198.0 \\
\hline Systemic appearance of exogenous & & \\
\hline $\begin{array}{l}{\left[{ }^{13} \mathrm{C}\right] \text { glucose, } \mathrm{g}} \\
\text { Exogenous }\left[{ }^{13} \mathrm{C}\right] \text { glucose retained in }\end{array}$ & $130.7 \pm 15.8$ & $133.4 \pm 5.9$ \\
\hline the splanchnic bed, $g$ & $77.0 \pm 15.8$ & $64.6 \pm 5.9$ \\
\hline $\begin{array}{l}\text { Suppression of basal hepatic glu- } \\
\text { cose production, } \%\end{array}$ & $59.9 \pm 8.3$ & $69.7 \pm 5.7$ \\
\hline
\end{tabular}

Values are means \pm SE $(n=5)$. Native ("slow") and pregelatinized ("rapid") cornstarches were supplied by Roquette Industries, Lestrem, France.

$\mu \mathrm{mol} \cdot \mathrm{kg}^{-1} \cdot \mathrm{min}^{-1}$ at $90 \mathrm{~min}$ and $61.63 \pm 7.43 \mu \mathrm{mol}$. $\mathrm{kg}^{-1} \cdot \mathrm{min}^{-1}$ at $75 \mathrm{~min}$, respectively, after slow starch and rapid starch meals $(P=0.80)$ (Fig. 5). As calculated by the area under the curve, the cumulated amount of

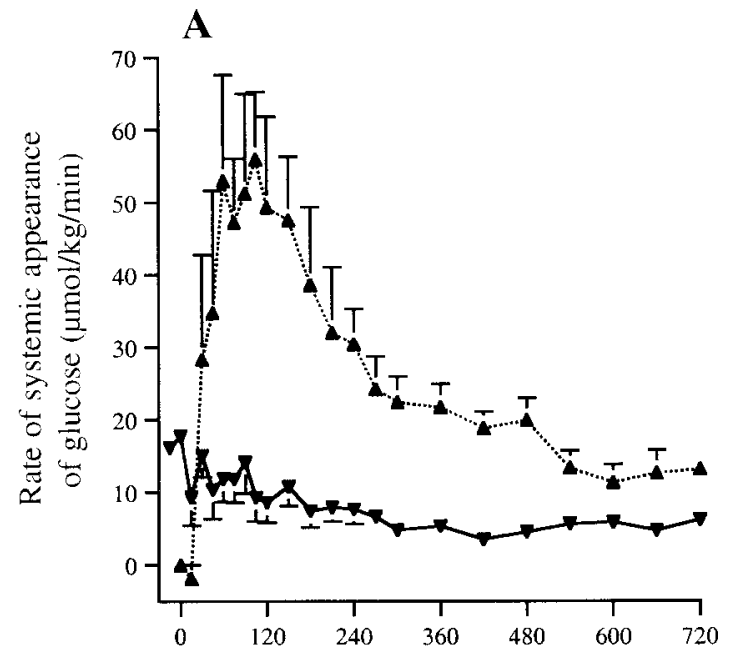

Time $(\min )$

B

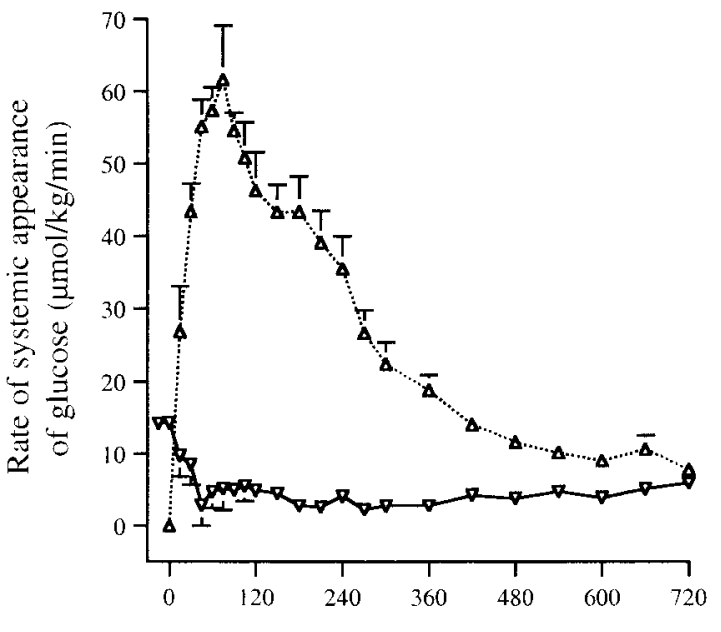

Time (min)

Fig. 5. Rates of systemic appearance of endogenous ( $\nabla, \nabla$ in $A)$ and exogenous $(\boldsymbol{\Delta}, \Delta$ in $B)$ glucose for native starch meal $(A)$ and pregelatinized starch meal (B). Values are means $\pm S E ; n=5$. Time 0 is beginning of experimental meal. 
exogenous glucose appearing at the peripheral level was $130.7 \pm 15.8 \mathrm{~g}(\mathrm{n}=5)$ for slow starch and $133.4 \pm$ $5.9 \mathrm{~g}(\mathrm{n}=5)$ for rapid starch during the $720 \mathrm{~min}$ of the experiment. Thus, respectively, $77.0 \pm 15.8 \mathrm{~g} \mathrm{(37.1 \pm}$ $7.6 \%$ of the ingested load) and $64.6 \pm 5.9 \mathrm{~g}(32.6 \pm 3.0 \%$ of the ingested load) were retained in the splanchnic area ( $P=0.68)$ (Table 2). Actually, in the present study, splanchnic glucose retention was found to be equivalent to gut glucose retention.

Comparison of arteriovenous difference and isotope dilution data. The cumulated amounts of $\left[{ }^{13} \mathrm{C}\right] \mathrm{glucose}$ appearing in the portal vein (calculated using the net balance across the gut, or the net balance corrected for the extraction of circulating $\left[{ }^{13} \mathrm{C}\right] \mathrm{gl}$ ucose) and the cumulated amounts of $\left[{ }^{13} \mathrm{C}\right] g$ lucose appearing in systemic blood (calculated using the isotope dilution method) were determined for slow and rapid starches (Fig. 6). With either test meal, the values calculated by the
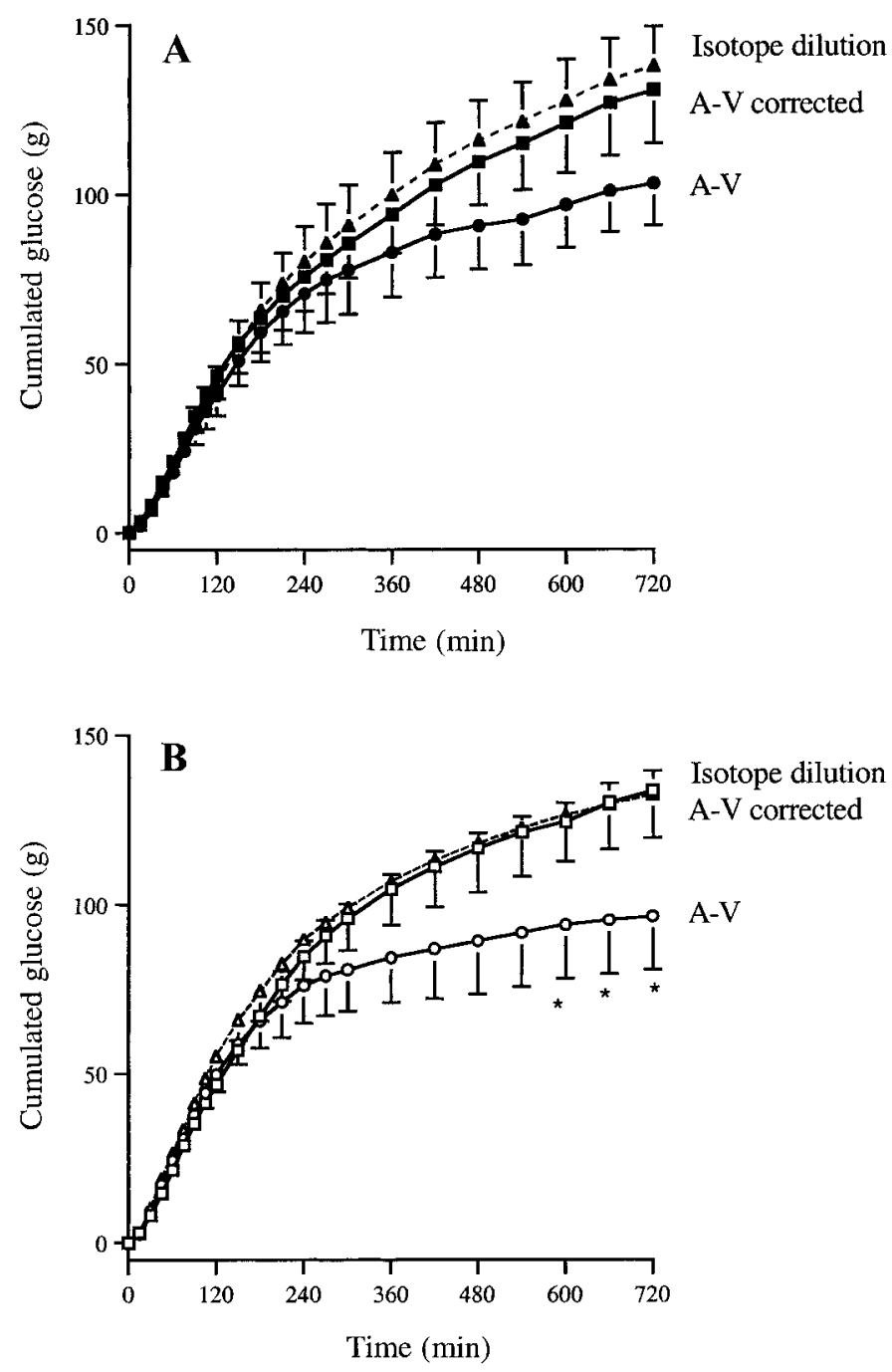

Fig. 6. Cumulated amounts of glucose calculated by isotope dilution method (squares) and arteriovenous difference ( $A-V)$ method without correction (circles) and after correction for gut extraction of circulating $\left[{ }^{13} \mathrm{C}\right]$ glucose (triangles) for slow starch (A) and rapid starch (B). Values are means $\pm S E ; n=5$. *Significant $(P<0.05)$ difference between A-V data uncorrected (circles) and other data (triangles and squares). Time 0 is beginning of experimental meal. different methods were similar during the first $240 \mathrm{~min}$ of the study. Then, values obtained by the arteriovenous difference method, uncorrected for the extraction of circulating $\left.{ }^{[13} \mathrm{C}\right]$ glucose, became lower than the values calculated by the isotope dilution method. For both meals, the cumulated amounts of glucose determined by the isotope dilution technique at $720 \mathrm{~min}$ were $\approx 25 \%$ higher than those obtained with thearteriovenous difference method. Values were significantly different between thetwo methods at $600 \mathrm{~min}, 660 \mathrm{~min}$, and 720 min only for the rapid starch meal $(P<0.05)$. When corrected for the extraction of circulating $\left[{ }^{13} \mathrm{C}\right] \mathrm{glu}$ cose, the values calculated by the arteriovenous difference method were similar to those determined by isotope dilution.

\section{DISCUSSION}

Splanchnic metabolism of glucose from a slowly or rapidly digested starch was considered in this study. The pig, because of its physiological similarities with humans, was used as the animal model (18). Splanchnic glucose metabolism was assessed simultaneously with the arteriovenous difference technique (to measure net glucose absorption) and the isotope dilution (dual tracer) technique, after the pigs had received isocaloric $(5,720 \mathrm{~kJ})$ meals containing $\approx 53 \%$ of their energy intake as starch.

A low average blood flow rate was found after the test meals $\left(\approx 25.5 \mathrm{ml} \cdot \mathrm{kg}^{-1} \cdot \mathrm{min}^{-1}\right)$ compared with the range of values reported for pigs $\left(24-40 \mathrm{ml} \cdot \mathrm{kg}^{-1} \cdot \mathrm{min}^{-1}\right)(2,8$, 24). However, because the transit time ultrasound method has been validated in vivo (7), measurements may depend on the amount and type of diet rather than on the technique used. Moreover, no development of collateral circulation in the portal system was observed when pigs were autopsied at the end of each experiment.

In basal state, the rate of glucose utilization by the gut was $\approx 7.3 \mu \mathrm{mol} \cdot \mathrm{kg}^{-1} \cdot \mathrm{min}^{-1}$. During absorption, the gut switched from net glucose utilization to net glucose release. However, it is remarkable that glucose utilization by the gut increased substantially in the meal fed condition. The gut used both luminal glucose from starch digestion, and vascular glucose, whose rate of utilization increased during absorption. The extraction ratio of vascular glucose decreased between 30 and 90 min after the meals, but arterial glucose was still partially extracted by the gut during absorption, mainly in the latest phase of this absorption (after the first 240 min of the study). For both starches, the rate of utilization increased during absorption. Abumrad et al. (1) showed that glucose utilization by the gut is increased during absorption. Although Vaugelade et al. (32) observed a decreased glucose oxidation capacity of enterocytes in postprandial conditions (in the presence of glutamine), they reported a high glycolytic capacity for the intestinal muscular layer, which may have contributed to the metabolism of both endogenous glucose and $\left.{ }^{13} \mathrm{C}\right]$ glucose (from starch digestion) in our study. 
Absorption of $\left[{ }^{13} \mathrm{C}\right]$ glucose tended to be higher during the first $105 \mathrm{~min}$ after the rapid starch meal. The pig has high digestive capacities (18), which may explain why the difference in the rates of glucose absorption for the two starches was not as large as expected from in vitro results. The proportion of ingested $\left.{ }^{13} \mathrm{C}\right]$ glucose equivalent that appeared in the portal vein was low $(\approx 50 \%)$ for both test meals. However, when the values

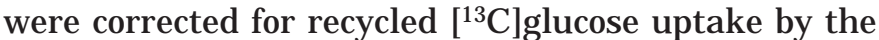
intestine, the proportion of ingested $\left[{ }^{13} \mathrm{C}\right]$ glucoseequivalent entering the portal vein ( $\approx 65 \%$ for both meals) was more in accordance with the $70-80 \%$ generally measured after a pure glucose load $(1,2)$. On the basis of these last data, the gut would have retained $\approx 35 \%$ of the dietary glucose load $(\approx 70 \mathrm{~g})$ during the postprandial study period. However, this proportion is overestimated, because absorption was not fully ended $12 \mathrm{~h}$ after the meals. Indeed, the rates of $\left[{ }^{13} \mathrm{C}\right]$ glucose portal flux were still $6.5 \pm 4.6 \mu \mathrm{mol} \cdot \mathrm{kg}^{-1} \cdot \mathrm{min}^{-1}$ (slow starch) and $6.0 \pm 1.9 \mu \mathrm{mol} \cdot \mathrm{kg}^{-1} \cdot \mathrm{min}^{-1}$ (rapid starch) at the end of our experimental period.

Part of the ingested starch was metabolized by the gut into lactate. After both test meals, lactate production by the gut $(\approx 7 \mathrm{~g})$ accounted for $3.5 \%$ of theingested glucose equivalent, which is in agreement with values found in different species $(1,24,30)$. Only minor gut production of alanine (3-5\% of the glucose equivalent ingested) has been reported after an oral glucose load (1) or a mixed meal (17). Therefore, the fraction of the ingested glucose equivalent lacking in the balance $(\approx 30 \%)$ must be related either to the conversion of glucose into other metabolites (such as $\mathrm{CO}_{2}$, for example) or to the uncompleted absorption at the end of the study. It is unlikely that part of the starch was fermented in the gut, because short-chain fatty acid concentration in ileal residues did not increase during the experiment (studies in one pig; results not shown) and little carbohydrate entered the colon in either animal (see RESULTS).

Basal glucose production (14- $17 \mu \mathrm{mol} \cdot \mathrm{kg}^{-1} \cdot \mathrm{min}^{-1}$ ) was similar to that reported for pigs $(10,19)$ and slightly higher than thevalues of $8-13 \mu \mathrm{mol} \cdot \mathrm{kg}^{-1} \cdot \mathrm{min}^{-1}$ observed for humans $(9,13,16,23,29)$. In the present article, the systemic appearance of glucose was calculated according to the single-compartment model described by Steele (26), which has mainly been used for glucose metabolism studies $(22,25,29)$. This model does not really describe the complex physiology of glucose metabolism but is reliable at slow turnover rates (4). Moreover, although an error due to the use of too low a glucose distribution volume $(V=0.2 \mathrm{l} / \mathrm{kg})$ has been found, it was shown to be partly counterbalanced by glucose recycling (16). The systemic appearance of exogenous glucose was not different for the two experimental meals. The similar cumulated amounts of ${ }^{\left[{ }^{13} \mathrm{C}\right] g l u c o s e}$ calculated by the isotope dilution and arteriovenous difference techniques during the first 240 min of the study suggest that hepatic fractional extraction of absorbed glucose was low $(9,23)$. After 240 min for both test meals, the cumulated amounts of $\left[{ }^{13} \mathrm{C}\right]$ glucose calculated by the isotope dilution method were higher $(\approx 25 \%$ higher at $720 \mathrm{~min})$ than those calculated by the arteriovenous difference technique. Glucose recycling, via gluconeogenesis (11), might account for part of the discrepancy observed between stable isotope and arteriovenous difference data. However, it has been shown after a pure glucose load that the rate of glucose recycling is low during 240-360 min after the oral load $(13,16)$. It was also suggested that exogenous glucose (newly absorbed) may be taken up first by the liver and incorporated into the glycogen pool before being released into the systemic circulation at the end of the study period. Indeed, Moore et al. (17) reported net hepatic release of absorbed $\left[{ }^{13} \mathrm{C}\right]$ glucose tracer in dogs 300 min after the ingestion of a mixed meal. Our findings do not support this hypothesis, because at no period of the study were the arterial glucose ${ }^{13} \mathrm{C}$ enrichments higher than the portal glucose ${ }^{13} \mathrm{C}$ enrichments. Moreover, when the cumulated amounts of $\left[{ }^{13} \mathrm{C}\right]$ glucose obtained by arteriovenous difference were corrected for recycled $\left[{ }^{13} \mathrm{C}\right]$ glu cose uptake by the intestine, they were similar to those calculated for isotope dilution. This suggests that the difference between the two methods might only be related to the extraction of recirculating exogenous glucose by the gut. Our findings are consistent with an appropriate use of the isotope dilution method as an alternative approach to measure the rate of $\left[{ }^{13} \mathrm{C}\right]$ glucose absorption.

In conclusion, the concomitant use of arteriovenous balance across the gut and isotope tracers showed that glucose utilization by the gut increased substantially during absorption and that this was unaffected by the nature of the starch ingested.

Address for correspondence and reprint requests: $M$. Champ, INRA, rue de la Géraudière, BP 71627, 44316 Nantes, Cedex 03, France (E-mail: champ@antes.inra.fr).

Received 25 February 1999; accepted in final form 15 September 1999.

\section{REFERENCES}

1. Abumrad, N. N., A. D. Cherrington, P. E. Williams, W. W. Lacy, and D. Rabin. Absorption and disposition of a glucose load in the conscious dog. Am. J . Physiol. Endocrinol . Metab. 242: E398-E406, 1982

2. Bjorkman, O., M. Crump, and R. W. Phillips. Intestinal metabolism of orally administered glucose and fructose in Yucatan miniature swine. J . Nutr. 114: 1413-1420, 1984.

3. Bornet, F. R.J ., A. M. Fontvieille, S. Rizkalla, P. Colonna, A. Blayo, C. Mercier, and G. Slama. Insulin and glycemic re sponses in healthy humans to native starch processed in different ways: correlation with in vitro $\alpha$-amylase hydrolysis. Am. J Clin. Nutr. 50: 315-323, 1989.

4. Cobelli, C., A. Ruggeri, G. Toffolo, A. Avogaro, and R. Nosadini. Is the "pool-fraction" paradigm a valid model for assessment of in vivo turnover in non-steady state? Am. J. Physiol. Regulatory Integrative Comp. Physiol. 245: R624-R632, 1983.

5. De Bodo, R. C., R. Steele, N. Altzuler, A. Dunn, and J . S. Bishop. On the hormonal regulation of carbohydrate metabolism: studies with 14C glucose. Recent Prog Horm. Res. 19: 445-448, 1963.

6. Dillon, R. S. I mportance of the hematocrit in interpretation of blood sugar. Diabetes 14: 672-674, 1965.

7. E isemann, J . H., G. B. Huntington, and C. L. Ferrell. Blood flow to hindquarters of steers measured by the transit time 
ultrasound and indicator dilution. J . Dairy Sci. 70: 1385-1390, 1987.

8. Ellis, P. R., F. G. Roberts, A. G. Low, and L. M. Morgan. The effect of high-molecular-weight guar gum on net apparent glucose absorption and net apparent insulin and gastric inhibitory polypeptide production in the growing pig: relationship to rheological changes in jejunal digesta. Br. J . Nutr. 74: 539- 556, 1995.

9. Ferrannini, E., O. Bjorkman, G. E. Reichard, A. Pilo, M. Olsson, J . Wahren, and R. A. DeFronzo. The disposal of an oral glucose load in healthy subjects. A quantitative study. Diabetes 34: 580-588, 1985.

10. Freeman, C. P., D. E. Noakes, and E. F Annison. The metabolism of glucose, acetate, palmitate, stearate and ol eate in pigs. Br. J . Nutr. 24: 705-716, 1970.

11. Hellerstein, M. K., R. A. Neese, J . M. Schwartz, S. Turner, D. Faix, and K. Wu. Altered fluxes responsible for reduced hepatic glucose production and gluconeogenesis by exogenous glucose in rats. Am. J . Physiol. Endocrinol. Metab. 272: E163-E172, 1997.

12. Higgins, J. A., J. C. Brand Miller, and G. S. Denyer. Development of insulin resistance in the rat is dependent on the rate of glucose absorption from the diet. J . Nutr. 126: 596-602, 1996.

13. Kelley, D., A. Mitrakou, H. Marsh, F. Schwenk, J . Benn, G. Sonnenberg, M. Arcangeli, T. Aoki, J . Sorensen, M. Berger, P. Sonksen, and J . Gerich. Skeletal muscle glycolysis, oxidation, and storage of an oral glucose load. J. Clin. Invest. 81: 1563-1571, 1988.

14. Laville, M., J. P. Riou, P. F. Bougnères, B. Canivet, $M$. Beylot, R. Cohen, P. Serusclat, C. Dumontet, F. Berthezene, and R. Mornex. Glucose metabolism in experimental hyperthyroidism: intact in vivo sensitivity to insulin with abnormal binding and increased glucose turnover. J . Clin. Endocrinol. Metab. 58: 960-965, 1985.

15. Lerer-Metzger, M., S. W. Rizkalla, J . Luo, M. Champ, M. Kabir, F. Bruzzo, F. Bornet, and G. Slama. Effect of long-term low glycaemic index starchy food on plasma glucose and lipid concentrations and adipose tissue cellularity in normal and diabetic rats. Br. J . Nutr. 75: 723-732, 1996.

16. Livesey, G., P. D. G. Wilson, J . R. Dainty, J . C. Brown, R. M. Faulks, M. A. Roe, T. A. Newman, J . Eagles, F. A. Mellon, and R. H. Greenwood. Simultaneous time-varying systemic appearance of oral and hepatic glucose in adults monitored with stable isotopes. Am. J . Physiol. Endocrinol. Metab. 275: E 717E 728, 1998

17. Moore, M. C., M. J . Pagliassoti, L. L. Swift, J . Asher, J . Murrell, D. Neal, and A. D. Cherrington. Disposition of a mixed meal by the conscious dog. Am. J. Physiol. Endocrinol. Metab. 266: E666-E675, 1994.

18. Moughan, P. J ., P. D. Cranwell, A. J . Darragh, and A. M. Rowan. The domestic pig as a model animal for studying digestion in humans. Proc. Int. Symp. Digestive Physiol. in Pigs 5th Bad Doberan Germany 1994, p. 389-396.
19. Müller, M. J ., U. Paschen, and H. J . Seitz. Effect of ketone bodies on glucose production and utilization in the miniature pig. J . Clin. Invest. 74: 249-261, 1984

20. Pagliassotti, M. J ., and P. A. Prach. Increased net hepatic glucose output from gluconeogenic precursors after high-sucrose diet feeding in male rats. Am. J. Physiol. Regulatory Integrative Comp. Physiol. 272: R526-R531, 1997.

21. Pfaffenberger, C. D., J . Szafranek, M. G. Horning, and E. C. Horning. Gas chromatographic determination of polyols and aldoses in human urine as polyacetates and aldonitrile polyacetates. Anal. Biochem. 63: 501-512, 1975.

22. Proietto, J ., F. Rohner-J eanrenaud, E. Ionescu, and J . Terretaz, J .-F. Sauter, and B. J eanrenaud. Non-steady state measurement of glucose turnover in rats by using a onecompartment model. Am. J. Physiol. Endocrinol. Metab. 252: E 77-E 84, 1987.

23. Radziuk, J ., T. J . McDonald, D. Rubenstein, and J . Dupre. Initial splanchnic extraction of ingested glucose in normal man. Metabolism 27: 657-669, 1978.

24. Rérat, A. A., P. Vaissade, and P. Vaugelade. Absorption kinetics of some carbohydrates in conscious pigs. 2. Quantitative aspects. Br. J . Nutr. 51: 517-529, 1984.

25. Rigalleau, V., M. Beylot, C. Pachiaudi, C. Guillot, G. Deleris, and H. Gin. Mehanisms of glucose intolerance during triglyceride infusion. Am. J. Physiol. Endocrinol. Metab. 275: E641-E648, 1998.

26. Steele, R. I nfluences of glucose loading and of injected insulin on hepatic glucose output. Ann. NY Acad. Sci. 82: 420-430, 1959.

27. Storlien, L. H., E. W. Kraegen, A. B. J enkins, and D. J . Chisholm. Effects of sucrose vs starch diets on in vivo insulin action, thermogenesis, and obesity in rats. Am. J . Clin. Nutr. 47: 420-427, 1988

28. Thivend, P., C. Mercier, and A. Guilbot. Determination of starch with glucoamylase. In: Methods in Carbohydrate Chemistry. New York and London: Academic, 1972, vol. II, p. 100- 105.

29. Tissot, S., S. Normand, R. Guilly, C. Pachiaudi, M. Beylot, M. Laville, R. Cohen, R. Mornex, and J . P. Riou. Use of a new gas chromatograph isotope ratio mass spectrometer to trace exogenous 13C-labelled glucose at a very low level of enrichment in man. Diabetologia 33: 449-456, 1990.

30. Van der Meulen, J., J . G. M. Bakker, B. Smits, and H. De Visser. Effect of source of starch on net portal flux of glucose, lactate, volatile fatty acids and amino acids in the pig. Br. J . Nutr. 78: 533-544, 1997.

31. van Leeuwen, P., D. J . van Kleef, G. J . M. van Kempen, J . Huisman, and M. W. A. Verstegen. The postvalve T-caecum cannulation techniquein pigs applied to determinethe digestibility of amino acid in maize, groundnut, and sunflower meal. J . Anim. Physiol. Anim. Nutr. 65: 183-193, 1991.

32. Vaugelade, P., L. Posho, B. Darcy-Vrillon, F. Bernard, M. T. Morel, and P. H. Duée. Intestinal oxygen uptake and glucose metabolism during nutrient absorption in the pig. Proc. Soc. Exp. Biol. Med. 207: 309- 316, 1994. 